\title{
From the Diary of a Leo Baeck Temple Rabbi
}

\author{
February 5, 1971
}

Inspired and provoked by the exposé of a young rabbinic colleague, Beerman explains here to his congregation what his weekly schedule looked like. The account mixed the poignant and the quotidian, while also unearthing some idiosyncrasies of the rabbi's calendar. Through this report, Beerman offers an illuminating profile of the peaks and valleys in the daily life of an American rabbi.

One of our colleagues has his yarmelke, his tallis, and the back of his head festooned on the cover of the January 18 edition of New York magazine. The tallis is authentically ordinary but the yarmelke is psychedelic. The piece our colleague has written is called "The Diary of a Suburban Rabbi."

Rabbi Martin Siegel leads a Reform congregation in Lawrence, Long Island, and like every rabbi he is looked upon to solve a variety of problems: Jewish fear of black anti-Semitism, the alienation of young people from the principles of Judaism, and the need to make the principles of Judaism work in relation to the problems of the day. The diary tells us how Rabbi Siegel copes with these matters and also how he must cope with other matters, the more personal problems: his wife's breakdown, his own job security, his child. Ultimately the private and public problems fuse, and the diary, which covers nine months of the Rabbi's life, creates the picture of a whole man.

The picture is blurred and divided as is the rabbi. He sees himself as a symbol. His people know him only by his roles. To some he is a radical; to some the signature on the marriage certificate; to some the man who opposes the indulgences of the psychotic fear of anti-Semitism. People see him, he says, only as they need to see him. And he can't recognize himself in their eyes. He and his wife have to live 
as exhibits in the community. People are friendly, but they have no friends. For the rabbi is not a reality; he is an abstraction.

The result is a very embittered young man who feels neglected by his congregants-his wife hospitalized, ignored in her hospitalization, so he says, by the members of the congregation-and he himself confused and divided, no longer performing his functions as he should.

It is not a very pretty picture, and depending on your knowledge of such matters you can be moved, touched, or outraged by the rabbi or his congregants. The fact is that these are real live people he talks about; the president of the congregation is mentioned by name. A week after the article appeared in New York the synagogue was filled to capacity when the rabbi arrived for the Shabbos service; it was like a Yom Kippur or a review of Portnoy's Complaint.

The success of Rabbi Siegel prompted the sermon title for tonight: "From the Diary of a Leo Baeck Temple Rabbi." It seemed, ten days ago, when I gave the title to Sylvia Wexler to list in the Bulletin, that it would be an easy enough thing to do. Every rabbi has at least an interior diary that he is convinced would make good reading. The daily experiences of our work present us with a wide range of experience wherein we touch so many of the facets of life-there is, in short, enough stuff there to fill a thousand lectures and sermons. But what I failed to consider was that the stuff of a rabbi's life does not make for public disclosure, necessarily. In fact what distressed me about Rabbi Siegel's piece in New York was precisely that he was willing to spill out the private experience for all to read. If I am distressed with the behavior of my congregation; if I think they are unkind, crude in their tastes, inhuman in their consideration of me and my family, what is accomplished by bringing the matter to the attention of the hundreds of thousands of strangers? well one thing is accomplished-money, fun, profit.

At any event, the experiences that fill my days and the fantasies that enrich my wakening and sleeping life are not exactly a fit subject for public disclosure, I learned, after I gave her [i.e., Sylvia Wexler] the title. That is the nature of the work itself-the confidences that are shared, and so forth, and they are not meant to be put on display-perhaps they should be saved for a work of fiction, or for the end of my days as a rabbi, whenever that will be.

But there can be at least a beginning tonight; it will be drawn from the experiences of many years, although it will be fitted into the days of a single week.

Monday-I dreaded this morning and felt some strange aches and pains, a slight dizziness; perhaps I had become the victim of a virus. Not enough to take refuge in, however-is that what I wanted, to take refuge in illness, or forgetfulness?? There was no such refuge. I had agreed to meet her in the waiting room at UCLA, where she would be receiving her cobalt therapy. Eight thirty, and I must be there, I had avoided her long enough. Isn't that what so often happens to people who are thought to have those hopeless diseases-they are avoided-avoided by me, avoided by their friends, avoided even by their doctors? Who is wise enough 
to know what to say under the circumstances, who is it that can move gracefully in such situations? For two years she had been fighting that cancer. I came to the hospital and there she was, smiling, talking to the people in that small room outside the room with the big awesome machine. Life and death are so filled with machinery, making it difficult to get through to the persons in us. "Well," she said, "we are going to try this new approach. The cancer has spread and we are hopeful that this will do it." Then I, trying to respond in some humor I saw in her language, said: "Who is the WE you are talking about-have you taken to using the plural of majesty - the royal we-and some phrase from Richard II came to my mind, 'we are amazed to wait thus long for the fearful bending of thy knee." "Oh," she said, "it is a we who are involved. I am alive today because of all of the people who have helped me through the various stages of this crisis. Where do you think I would be without the doctor who runs this department and the technicians who administer the equipment? It is not just me alone-it is we who are fighting this disease. It is nothing royal I am stating; it is not even modest; it is we."

The pains had disappeared when I made my way back to the temple. I had come to bring her some comfort and courage. And, as so often strangely happens, she had given it instead to me.

Tuesday-Money. Last night at the Board meeting was all about money, the money we didn't have-the almost 30,00o dollars we didn't have. Come April 1 there will not be enough money to pay salaries - to pay ME. We are so clumsy in this temple when it comes to money.

A man's character, the Talmud says, is revealed in these three ways: B'kiso, bicoso, b'kaaso, in his money pocket, in his cup, and in his anger. Like the rabbinic sages we too judge a man's character by his passion, or his anger, or, in words more familiar to our jargon, by his aggression or his hostility. And even as for his cup - the way a man handles his liquor - surely that too becomes a way of judging a man's character. We would observe a man at the end of two or three drinks and measure him by what alcohol has released in him. But when it comes to his pocket, his money pocket that is, the way he handles his money, makes his money, spends his money, what he buys, what he saves, what he keeps, what he gives-here we speak softly and act as though we are on some sacred ground-and perhaps we are. For money is a deity, a very visible deity. The pursuit of money is the common religion of all Americans, a quest which binds us together. It is not accidental that the coins of the realm bear the inscription IN GOD WE TRUST. That is our trust, our commitment, our ultimate concern, our God. There is no use pretending. We are all devoted adherents of the ritual, the pageantry, the dogma, of Money.

Around synagogues, suburban synagogues at least, we talk about budgets and building funds, and membership dues and the high cost of maintaining the whole enterprise-the whole disaster, but we do not talk about the meaning of money. And when we do talk about money, we always talk in delicate, silken tones, lest we offend. I remember that wonderful vibrant statement of Vinegar Joe Stillwell in 
Indo China during World War II. General Joseph Stillwell, commenting on some ultra patriotic critics of his, said: "The higher a man climbs on a flag pole, the more of his ass he shows to the public." And it was Shaw who said that "the higher a man climbs on the economic ladder the more things he becomes ashamed of." The more affluent we become, personally and institutionally, the more we become ashamed of dealing with money, realistically, honestly. We do reveal the scale of our values, our character-the rabbis were right by the manner in which we use our money. A man will put his money where his soul is. He will pay for the things that matter most to him, arrange them in the order of his priorities. That's enough to say about money.

Wednesday - a young man came to see me about getting married to a nonJewish girl. He had been in love before, three times, each time with a non-Jewish girl. Was that accidental? What is there about non-Jewish girls that makes them so attractive to him; or what is it about Jewish girls that might account for his not having found one to love? - well Jewish girls are more complicated, more demanding - or at least so it seemed to him. (And for him it was important that a girl not be demanding; in fact her function was to serve, to put him in first place-man must rule-numero uno.) Today I read a poem called "David Is Dying to Get Married."

David is dying to get married.

$\mathrm{He}$ is dying to share

His heart, his insights, and the unspoiled island in the Caribbean where he is the only American who goes there

With someone feminine enough and intelligent enough and mature enough to understand

That when he's hostile it's because he's feeling threatened,

And when he's vicious it's because he feels unloved,

And when he's paranoid, sadistic, depressed, or sexually inadequate

It's simply because

She has failed him. Yes

David is dying to get married.

He is dying to share

His fish tank, his discounts, and the unspoiled restaurant in

Chinatown where he is the only Caucasian who eats there

With someone secure enough and subtle enough and grateful enough

to understand

That when he's rigid it's because he has high standards,

And when he's violent it's because he has no choice,

And when he's manic, suicidal, or having trouble sleeping

It's simply because

She has failed him. Yes, 
David is dying to get married.

To a woman like Lauren Bacall but a bit more submissive.

To a woman like Melina Mercouri but a bit more refined.

To a woman who understands that in order to share

His loves, his hates, his hopes, his fears, his low license plate,

His high tax bracket and his rent-controlled apartment with the

terrace where he and his mother are the only people who live there

She better not fail him.

Thursday-Intermarriage again. A young couple came, very young, naïve-the girl did most of the talking. "Well, Rabbi, I feel it is very important to have religious unity in the home and that is why I wish to become a Jew. I come from a very religious home; my father is a deacon in our Methodist Church and I sang in the choir and taught Sunday school; religion is important to me and family unity is important and that's why I want to be a Jew." Turning to the young man, I said: "Why don't you achieve this unity by your becoming a Christian?" He sputtered out some answer. And to the young girl I said: "If religion, your religion is so important to you why become a Jew?" Her answer: "But, Rabbi, it's the Christian thing to do."

Friday-the Sabbath is coming, another service. How shall we ever resolve all of the questions and problems of that service? Will they, those Jews of ours, ever be able to pray? Will I be able to pray? What does it mean to pray? I cannot free myself completely from thinking of prayer as I did in my childhood. To pray is to ask for something - "oh God," the child in some grammar school prayed after taking an examination in geography - "oh God, please make San Diego the capital of California." Prayer cannot be that, at least not in any constant, significant way can it be that. Prayer must begin where one listens to a voice.

We cannot be sure what the voice is, but a voice nonetheless. And prayer must be a way of being reassured about our own uniqueness, and our equality with others.

Saturday-God rested on Saturday, but I, I like to play tennis. I would like a Shabbat in the park. The First Man was put into the Garden of Eden to dress it; we are here to look after the universe. We are here to help the universe achieve the goals it cannot realize by itself. The poet Auden says we are to think of ourselves as sculptors. No sculptor enforces his forms on nature. “The sculptor sees himself as laying bare, realizing in stone a form that is already there, potentially, or latently. We shall have a decent world when, and if we understood to treat everything as a sculptor, if we understood that to make a hideous lampshade is to torture helpless metals. When we make a nuclear weapon, we corrupt the morals of a host of innocent neutrons below the age of consent."

Sunday-religious school-I grow old, and I shall wear the bottoms of my trousers rolled ${ }^{1}$ - Kominsky says he does not like being a policeman on Sunday 
morning - and part my hair from behind. ${ }^{2}$ Some young people organized a project on ecology, caring about the environment. They are collecting newspapers and they in turn are collected from us. If we could convince the Los Angeles Times to cut the size of its Sunday edition in half, we would save more paper than all of the paper collected in a single week by the entire county of Los Angeles. But we will keep the environment cleaner, and spare nature somewhat through recycling and thus contribute to the Capitalist system. But what has this to do with Religious School or Judaism? Several telephone calls from parents, "I send my children to religious school to learn about being Jewish, not to collect newspapers." Is it Jewish to collect newspapers; is it Jewish to care about making a more human environment?

Monday again-A call from the Free Angela Davis Committee and the Committee for the Berrigan Brothers, and the Jewish Defense League, and UCLA all wanting to use our facilities so that someone can speak here. A disgruntled union calling, complaining about the labor practices of one of our members.

Another week has begun.

\section{COMMENTARY BY RABBI KENNETH CHASEN}

When I first read Rabbi Beerman's sermon, I was reminded of one of the Torah's most mysterious passages ... Numbers 19, which details the rules pertaining to the red heifer, an animal that was used in an ancient purification process for anyone who had touched a dead body. The person in question was to be sprinkled with the ashes of a perfect, unblemished red heifer cow on the third and seventh days after contact. This was supposed to purify him . . . but it was also said to leave the priest who had sprinkled the ashes in an impure state. Now he required healing.

One of my mentors, the longtime chaplain at Cedars-Sinai Medical Center in Los Angeles, Rabbi Levi Meier, of blessed memory, once wrote of this passage: "The person who heals becomes wounded by the experience."

Clearly, this is what has happened to Rabbi Siegel, and he hungers for healing of his own. But Rabbi Beerman offers us a different lens through which to view the everyday struggles and sufferings that accompany his service as the Healer-inChief of Leo Baeck Temple. He sees himself bearing all the consequences that his care for others has produced. However, he experiences his wounds not as lesions that must be treated. Rather, they are the hard-won portals through which wisdom, whimsy, and vision have entered him. Yes, there are cracks upon his surface. Some run quite a bit deeper than the surface. Yet as Leonard Cohen noted, "There are cracks in everything. That's how the light gets in."

Now, it is upon me to lead Leo Baeck Temple with Rabbi Beerman's awareness of the great gifts that come with being a wounded healer. We all get to decide what to make of our wounds ... 